\title{
Effect of Manure and NPK Fertilizers on Growth and Production of Onion (Allium cepa L.)
}

\author{
Maisura1*, Mulyadi Nurdin'1, Muslina1 $^{1}$ \\ ${ }^{1}$ Department of Agroecotechnology, Faculty of Agriculture, Universitas Malikussaleh. \\ Jl. Teungku Nie Reuleut, Muara Batu, Aceh Utara, Aceh, Indonesia \\ *Corresponding author: maisura@unimal.ac.id
}

\section{ARTICLE HISTORY}

Received : 17 February 2019

Revised : 12 March 2019

Accepted : 20 April 2019

KEYWORDS:

Manure

Inorganic fertilizers

Onion plants

Onion bulbs

Bulb yield

\begin{abstract}
Fertilization is one of efforts done by farmers to increase the production and quality of onions. This research aimed to find out the effect of manure and NPK fertilizers to the growth and production of onions. This research was conducted in Paloh Lada Village, Dewantara Sub-district, North Aceh and Agroecotechnology Laboratory, Faculty of Agriculture, Malikussaleh University from May to July 2018. This research used Randomized Block Design (RBD) Factorial The first factor was manure (P): 15 tons/ha (P1), 20 tons/ha (P2), 25 tons/ha (P3). The second factor was NPK fertilizers (N): $150 \mathrm{~kg} / \mathrm{ha}(\mathrm{N} 1), 200 \mathrm{~kg} / \mathrm{ha}(\mathrm{N} 2)$ and $250 \mathrm{~kg} / \mathrm{ha}$ (N3). The results indicated that there was high significant interaction between manure and NPK fertilizers on wet weight and dry weight of onion bulbs and also bulb yield. The application of manure significantly enhanced the wet weight and dry weight of onion bulbs and its production and it also significantly increased the plant height at 14 days after planting. The application of NPK increased the wet weight and production of onion bulbs significantly. Also, the combination application of manure 15 tons/ha and NPK fertilizers $150 \mathrm{~kg} /$ ha did improve the wet weight, dry weight and production of onion bulbs.
\end{abstract}

This is an open access article under the CC-BY-SA license.

\section{INTRODUCTION}

Onion plants are one of the eminent commodities which have been intensively cultivated by farmers for a long time. This commodity has been also a source of income and employment opportunities that contribute significantly to the economic development of the region. Onions have a high value economically which encouraged farmers in almost all provinces in Indonesia to cultivate the plants. Unfortunately, although they have strong encouragement in growing onions, but there are some obstacles in the business, technically and economically (Sumarni and Hidayat, 2005; Sinaga et al., 2016).

One of efforts has been done by farmers to increase the production and quality of yield bulb of onion is fertilizing the plants in order to increasing the availability of nutrients. However, these efforts often do not provide the expected improvement in yield due to several factors, such as applying inappropriate fertilization without considering the condition of the plants (Sumarni et al., 2012).

The growth and bulb yield of onion increased with the addition of 30 tons manure/ha of cow manure on the planting media (Mayun, 2007). Jumini et al. (2010) also stated that the application of 20 tons manure/ ha affected the number of bulb yield/clump, reached up to 7.56 bulbs. According to research of Latarang and Syakur (2006), application of 25 tons manure/ha increased yield with an average production of 6.30 tons/ha, 2.2 tons/ha increased compared to without manure application.

The application of NPK fertilizer can also increase the growth and production of onion. The application of balanced macro nutrients $(\mathrm{N}, \mathrm{P}$ and $\mathrm{K})$ is very much needed by younger plants because those macro nutrients can stimulate plant's vegetative growth such as roots, stems and leaves which improve the height of the plants. This is in accordance with the research of Rauf et al (2000). They reported that the elements N, P and K play important role in stimulating vegetative growth (stems and leaves) and $\mathrm{K}$ elements help the growth of plant's roots. This study aimed to evaluate the effect of manure and NPK fertilizers on the growth and production of onions.

\section{MATERIALS AND METHODS}

The materials used in this study were onion bulb variety Bima Brebes, manure, NPK fertilizers Mutiara (ratio 16:16:16), and fungicide Sagri-Bat. The tools used were hoes, shovels, knives, spray bottles, analytical balance, cameras and stationery. 
This study used a factorial Randomized Block Design (RBD) with 2 factors: manure doses and fertilizer doses. Manure with 3 different doses: P1 = 15 tons/ha, P2 = 20 tons/ha P3 = 25 tons/ha. The NPK Fertilizer with 3 different doses: $\mathrm{N} 1=150 \mathrm{~kg} / \mathrm{ha}, \mathrm{N} 2=200 \mathrm{~kg} / \mathrm{ha}, \mathrm{N} 3=$ $250 \mathrm{~kg} / \mathrm{ha}$. These experiments were replicated 3 times.

\section{Selection of Onion Seeds and Cultivation}

Larger and healthier seeds or bulbs with brighter color were selected. The planting land needed to be cultivated as deep as $20 \mathrm{~cm}$. The planting plots were made with a size of $1 \mathrm{~m} \times 1 \mathrm{~m}$ (27 plots). The distance between plots was 30 $\mathrm{cm}$ and the distance between blocks was $50 \mathrm{~cm}$, functioned as drainages.

\section{Fertilization}

Fertilizers were applied on each treatment bed. Manure is applied with a dose of 15 tons/ha (P1), 20 tons/ha (P2) and 25 tons / ha (P3) and it should be applied one week before planting. NPK fertilizers were also applied with a dose of $150 \mathrm{~kg} / \mathrm{ha}(\mathrm{N} 1), 200 \mathrm{~kg} / \mathrm{ha}$ (N2) and $250 \mathrm{~kg} / \mathrm{ha}$ (N3). These fertilizers were applied 3 days before planting.

\section{Mulch Installation}

Mulching was installed 2 days before planting. The experimental plots were applied with enough water and were left for 2 hours before the application of mulch. The mulch installed by gluing the ends of mulch using bamboo and after that, planting plots were made by using milk cans containing hot charcoal.

\section{Planting}

Onion bulbs were planted in planting holes $(25 \mathrm{~cm} \times 25$ $\mathrm{cm}$ ). Before planting, $1 / 4 \mathrm{~cm}$ cut at the ends of bulbs then they were planted in an upright position covered with soil. One planting hole consisted one onion bulb. The cultivation was done in the morning.

\section{Harvesting}

At 60 days after planting, where the leaves are thinning and yellowing and 60-70\% yield bulbs are red and firm, onions were ready to be harvested. Harvesting is done by removing the entire plant carefully in order to avoid the bulbs to be left behind, and then they were cleaned.

\section{Observations}

The observations were made on the growth and yield such as plant height $(\mathrm{cm})$, number of leaves, number of bulbs/clump, wet weight of bulbs/clump (g), dry weight of bulbs/clump (g), bulb diameter ( $\mathrm{cm}$ ) yield bulb of onions bulbs (tons).

\subsection{Statistical Data Analysis}

The data collected subjected to $\mathrm{F}$ test and the means then compared using DMRT at 0.05 probability level.

\section{RESULTS AND DISCUSSIONS}

\subsection{Results}

The results were illustrated in Tables 1-5. The results of ANOVA showed that there was a significant interaction between the application of manure and NPK fertilizers on the wet weight and dry weight of bulbs/clump and also yield of onion bulbs (Tables 3, 4 and 5). The individual tests using manure possessed significant effect on wet weight, dry weight of bulbs/clump and yield of onion bulbs. Furthermore, the use of NPK fertilizer alone also increased wet weight, dry weight of bulbs/clump and yield of onion bulbs significantly (Tables 3, 4 and 5) However, there is no interaction between the application of manure and NPK fertilizers on the number of bulbs/clump and diameter of bulbs (Tables 1 and 2).

Table 1. Number of bulbs/clump of onion plants treated with manure and NPK fertilizers.

\begin{tabular}{cc}
\hline \multicolumn{1}{c}{ Treatments } & Number of bulbs \\
\hline Panure (P) & \\
P2 (20 tons/ha) & $6.58 \mathrm{a}$ \\
P3 (25 tons/ha) & $6.47 \mathrm{a}$ \\
\end{tabular}

\begin{tabular}{cc}
\hline \multicolumn{1}{c}{ NPK Fertilizers (N) } & \\
\hline N1 $(150 \mathrm{~kg} / \mathrm{ha})$ & $6.88 \mathrm{a}$ \\
N2 $(200 \mathrm{~kg} / \mathrm{ha})$ & $6.36 \mathrm{a}$ \\
N3 $(250 \mathrm{~kg} / \mathrm{ha})$ & $6.77 \mathrm{a}$ \\
\hline
\end{tabular}

Means followed by the same letters do not differ significantly $(\mathrm{P}=0.05)$ as determined by DMRT.

Table 2. Diameter of bulbs of plants treated with manure and NPK fertilizers

\begin{tabular}{lc}
\hline \multicolumn{1}{c}{ Treatments } & Diameter $(\mathrm{cm})$ \\
\hline Manure (P) & \\
\hline PI (15 tons/ha) & $1.77 \mathrm{a}$ \\
P2 (20 tons/ha) & $1.72 \mathrm{a}$ \\
P3 (25 tons/ha) & $1.62 \mathrm{a}$
\end{tabular}

\begin{tabular}{lc}
\hline \multicolumn{2}{c}{ NPK Fertilizers (N) } \\
\hline N1 (150 kg/ha) & $1.59 \mathrm{a}$ \\
N2 (200 kg/ha) & $1.65 \mathrm{a}$ \\
N3 (250 kg/ha) & $1.87 \mathrm{a}$ \\
\hline Means followed by the same letters do not differ significantly $(\mathrm{P}=0.05)$ as
\end{tabular}

Means followed by the same letters do not differ significantly $(\mathrm{P}=0.05)$ as determined by DMRT.

Table 3. Wet weight of bulbs of plants treated with manure and NPK fertilizers.

\begin{tabular}{cccc}
\hline \multirow{2}{*}{ Manure (P) } & \multicolumn{3}{c}{ NPK fertilizers (N) } \\
\cline { 2 - 4 } & $\mathrm{N} 1(150 \mathrm{~kg} / \mathrm{ha})$ & $\mathrm{N} 2(200 \mathrm{~kg} / \mathrm{ha})$ & $\mathrm{N} 3(250 \mathrm{~kg} / \mathrm{ha})$ \\
\hline $\mathrm{P} 1$ & $32.28 \mathrm{~b}$ & $32.17 \mathrm{~b}$ & $20.18 \mathrm{a}$ \\
$(15$ tons $/ \mathrm{ha})$ & $\mathrm{B}$ & $\mathrm{B}$ & $\mathrm{A}$ \\
$\mathrm{P} 2$ & $16.10 \mathrm{~b}$ & $36.29 \mathrm{c}$ & $26.56 \mathrm{~b}$ \\
$(20$ tons $/ \mathrm{ha})$ & $\mathrm{A}$ & $\mathrm{C}$ & $\mathrm{B}$ \\
$\mathrm{P} 3$ & $18.03 \mathrm{a}$ & $18.16 \mathrm{a}$ & $32.81 \mathrm{~b}$ \\
$(25$ tons/ha) & $\mathrm{AB}$ & $\mathrm{A}$ & $\mathrm{C}$ \\
\hline Means followed by the same letters do not differ significantly $(\mathrm{P}=0.05)$ as
\end{tabular}
determined by DMRT. 
Table 4. Dry weight of bulbs of plants treated with manure and NPK fertilizers

\begin{tabular}{cccc}
\hline \multirow{2}{*}{ Manure (P) } & \multicolumn{3}{c}{ NPK fertilizers (N) } \\
\cline { 2 - 4 } & $\mathrm{N} 1(150 \mathrm{~kg} / \mathrm{ha})$ & $\mathrm{N} 2(200 \mathrm{~kg} / \mathrm{ha})$ & $\mathrm{N} 3(250 \mathrm{~kg} / \mathrm{ha})$ \\
\hline $\mathrm{P} 1$ & $25.89 \mathrm{~b}$ & $26.63 \mathrm{~b}$ & $17.50 \mathrm{a}$ \\
$(15$ tons/ha) & $\mathrm{B}$ & $\mathrm{B}$ & $\mathrm{A}$ \\
$\mathrm{P} 2$ & $13.22 \mathrm{a}$ & $30.72 \mathrm{c}$ & $20.97 \mathrm{~b}$ \\
$(20$ tons/ha $)$ & $\mathrm{A}$ & $\mathrm{C}$ & $\mathrm{B}$ \\
$\mathrm{P} 3$ & $15.24 \mathrm{a}$ & $14.88 \mathrm{a}$ & $25.93 \mathrm{~b}$ \\
(25tons/ha) & $\mathrm{AB}$ & $\mathrm{A}$ & $\mathrm{C}$ \\
\hline
\end{tabular}

Means followed by the same letters do not differ significantly $(\mathrm{P}=0.05)$ as determined by DMRT.

Table 5. Yield bulb of onions treated with manure and NPK fertilizers

\begin{tabular}{cccc}
\hline \multirow{2}{*}{$\begin{array}{c}\text { Manure } \\
\text { (P) }\end{array}$} & \multicolumn{3}{c}{ NPK Fertilizers $(\mathrm{N})$} \\
\cline { 2 - 4 } & $\mathrm{N} 1(150 \mathrm{~kg} / \mathrm{ha})$ & $\mathrm{N} 2(200 \mathrm{~kg} / \mathrm{ha})$ & $\mathrm{N} 3(250 \mathrm{~kg} / \mathrm{ha})$ \\
\cline { 2 - 4 } P1 & $5.16 \mathrm{a}$ & $5.14 \mathrm{a}$ & $3.32 \mathrm{a}$ \\
$(15$ tons $/ \mathrm{ha})$ & $\mathrm{B}$ & $\mathrm{AB}$ & $\mathrm{A}$ \\
\hline $\mathrm{P} 2$ & $2.57 \mathrm{a}$ & $5.80 \mathrm{~b}$ & $4.24 \mathrm{ab}$ \\
$(20$ tons $/ \mathrm{ha})$ & $\mathrm{A}$ & $\mathrm{B}$ & $\mathrm{A}$ \\
\hline $\mathrm{P} 3$ & $2.88 \mathrm{a}$ & $2.90 \mathrm{a}$ & $5.24 \mathrm{a}$ \\
$(25$ tons $/$ ha $)$ & $\mathrm{AB}$ & $\mathrm{A}$ & $\mathrm{A}$ \\
\hline
\end{tabular}

Means followed by the same letters do not differ significantly $(\mathrm{P}=0.05)$ as determined by DMRT.

\subsection{Discussions}

From the data analysis, it is revealed that the application of manure and NPK fertilizers did not increase the number of bulbs/clump significantly. The number of bulb yield in different doses of manure and NPK fertilizers showed that ordinarily the plants produced a small amount of bulbs in each treatment. As matter of fact, variety Bima Brebes has potential to produce 7-12 bulbs/plant. This deterioration is possible to happen due to its genetic factor. This result is in corroboration with the research of Sumarni et al (2012) that the number of tillers or the number of bulbs was more determined by genetic factors than environmental factors such as fertilization.

Although the results (yield bulb of onions and diameter of bulbs) obtained from the research was not in agreement with several previous researches described above, but parameter bulb weight/clump possessed an interaction between plants treated with manure and NPK fertilizers. It can be said that the doses given can increase weight of bulbs both wet and dry weight and also yield bulbs. The results revealed that the mixture of 20 tons of manure/ha with $200 \mathrm{~kg}$ NPK fertilizer/ha have improved weight and production of onion bulbs. These findings indicated that there were sufficient nutrient contents (nitrogen, phosphorus and potassium) in the soil that helped the plants to grow better. Napitupulu and Winarto (2009) found that potassium played an important role in increasing vegetative growth of plants such as plant formation, enlargement and elongation of bulbs which have influenced in increasing the weight of onions. Damanik et al (2010) also revealed that potassium is needed for photosynthesis and it can increase bulbs weight. Sutrisna et al (2003) have investigated that the balance of nutrients, especially $\mathrm{K}$ (potassium) in the soil played an important role in the synthesis of carbohydrates and proteins so that it helped to enlarge the onion bulbs significantly.
Increasing the dose of NPK fertilizers mixed with manure did not increase the weight of onion bulbs and bulb yield. These results were described in Tables 3, 4 and 5. Each plant needed to be fertilized with the appropriate dose so that there is a balance of nutrients in the soil which enables plants to grow and develop well and produce optimum production. This is in accordance with the findings of Bybordi and Malakouti (2003). They reported that application of sufficient $\mathrm{K}$ fertilizer in soil optimized the growth of onions. The addition of potassium (K) with high dose exhibited good results due to its role to help the plants in photosynthesis. It helped the formation of new organic compounds that are transported to bulbs. Sinaga et al (2016) found that K fertilizer increased the plant height. Overall, K fertilizer improved the bulb quality.

\section{CONCLUSION}

From the results obtained, it can be concluded that the application of manure 15 tons/ha and NPK fertilizers 150 $\mathrm{kg} / \mathrm{ha}$ did improve the wet weight, dry weight and production of onion bulbs.

\section{References}

Bybordi, A., and M.J. Malakouti. 2003. The Effect of Various Rates of Potassium, Zinc, and Copper on the Yield and Quality of Onion Under Saline Conditions In Two Major Onion Growing Regions of East Azarbayjan. Agric. Sci. and Technol 17, 43-52.

Damanik, M. M. B., B. E, Hasibuan., Fauzi., Sarifuddin. And H, Hanum. 2010. Soil Fertility and Fertilization (written in Indonesian language). USU Press. Medan

Jumini., Sufyati, Y., and Fajri, N. 2010. Effect of cutting seed bulbs and types of organic fertilizer on the growth and yield of onions (written in Indonesian language). J. Floratek 5: 164-171.

Latarang, B and Abd. Syakur. 2006. Growth and yield of red onion (Allium ascalonicum L.) at various manure doses (written in Indonesian language). Script. Tadulako University, Palu.

Mayun, IA. 2007. Effect of rice straw mulch and manure on the growth and yield of onions in coastal areas (written in Indonesian language). J Agritop, 26 (1): 33-40.

Napitupulu, D. And L. Winarto. 2009. Effect of N and K fertilizers on the growth and production of onions (written in Indonesian language. Jurnal Hortikultura, 20 (1): 27-3.

Sinaga, S.F., Toga. Sand Yaya, H. 2016. Response to the growth of onions (Allium ascalonicum L.) to the application of waste compost and $\mathrm{K}$ fertilizer (written in Indonesian language). Jurnal Agroekoteknologi, 4 (3): 2181-2187.

Sumarni, N and A, Hidayat. 2005. Onion Cultivation (written in Indonesian language). Vegetable Crop Research Institute. Bandung, pp. 19-22.

Sumarni, N., R, Rosliani., R.S, Basuki., And Y. Hilman. 2012. Effect of Varieties, K status in soil and dose of K Fertilizer on Growth, Bulb Yield, and Nutrient Absorption of Red Onion Plants (written in Indonesian language). Vegetable Crop Research Institute. Bandung.

Sutrisna, N., S. Suwalan, and Ishaq. 2003. Technical and financial feasibility tests for the use of inorganic NPK fertilizers applied to potato crops at highland in West Java (written in Indonesian language). J. Hort. 13 (1): 67-75.

Rauf, A. W., Syamsuddin, T., Sri, R. S., 2000. Role of NPK Fertilizers in Rice Plants. Agriculture Department (Written in Indonesian language). Agricultural Research and Development Agency. West Koya Agricultural Technology Study Site. Irian Jaya. 